\title{
EMERGING BUSINESS AND HUMAN RIGHTS STANDARDS: INTERNET SERVICE PROVIDERS AND CENSORSHIP DEMANDS
}

CAROLLANN BRAUM, J.D., LL.M.

Over the past several decades, the world has seen a dramatic growth in the activities of global businesses and multinational corporations. While this expansion has led to an increase in the availability of goods and services around the world, with it has also come more occurrences of human rights violations often at the hands or behest of corporations. Yet the role of businesses in human rights also often involves corporate complicity when countries violate human rights. Many of these violations have been clearly brought to the public's attention, such as the use of sweatshops in developing countries. There is no question that as corporations play a greater role in our society, the possibility they have for both advancement and human rights abuse have the potential to increase hand-in-hand. However, there has been great debate over the accountability that corporations should have if and when they violate human rights.

While human rights have traditionally been a domain for state governments, there has been a growing discussion on the role businesses play in ensuring human rights (Office of the High Commissioner for Human Rights). Businesses often involved in human rights protection or responsible for human rights infringements include, but are not limited to, those in manufacturing, information and communication technology, mining, oil and energy extraction, agribusiness, banking, and finance. Over the past several years, the world has seen increased pressure on corporations to close down sweat shops or adopt less environmentally harmful practices, thereby protecting local populations. However, the extent that a business can be held legally responsible for human rights violations and, consequently, obligated to provide remedies for such violations, has been the subject of much debate.

With the increasingly significant role of corporations in the world, it should come as no surprise that the area of Business and Human Rights has been developing rapidly in recent years, both in the private sector and the international legal arena. The United Nations has endorsed a set of Guiding Principles, which outline globally accepted standards on the responsibilities of both businesses and governments to prevent and address human rights issues arising from business activities (Guiding Principles, 2011). In 2013, the United Nations hosted the Second Annual Forum on Business and Human Rights, the largest global discussion on the subject to date. On the other end of the spectrum, many businesses and industries have taken it upon themselves to generate human rights standards and ethical practices, often through the notion of corporate social responsibility. While there has been some case law regarding the responsibility of businesses when human rights are in question, much of the adherence to standards is voluntary and a decision left to the individual industries or companies (Ku, 2011). 
This article will focus on the legal regulations of businesses in a position to protect or violate human rights. The case in point concerning Internet Service Providers (ISPs) operating in countries that require censorship, thereby raising questions of the freedoms of expression and information which are enshrined in international human rights law, will seek to create an understanding of the ways in which businesses are obliged to consider human rights law. Certainly, there are examples of very grave human rights violations, but the example of ISPs and censorship is much more widespread and likely an issue that may continue to have an impact on people across the globe (Global Network Initiative Inaugural Report, 2010). In order to create a more focused picture of the situation, this article will use the example of Google's choice to operate in China by balancing censorship requirements with the drive to do business in a huge market. As such, the obligations of an ISP to protect human rights in the context of censorship will be the example throughout this discussion.

\section{INTERNATIONAL HUMAN RIGHTS LAW}

\section{INTERNATIONAL BILL OF RIGHTS}

Before going into further detail about the responsibility of corporations, it is important to understand specifically what is meant by human rights and to illustrate the potential difficulty in applying human rights obligations to corporations. There is no one definition of what are considered to be human rights. Certainly, the Universal Declaration of Human Rights is the best source for identifying human rights and it includes the right to life, freedom from discrimination of all kinds, freedom from torture, freedom of expression and many others (Universal Declaration of Human Rights, 1948). However, as the law generally goes, human rights law is always evolving to include new rights or modify old ones to meet the needs of the current global society. This is often done through new treaties, such as the International Covenants on Civil and Political Rights and Economic, Social and Cultural Rights, as well as treaties covering race, women, children and more (International Convention on the Race Discrimination, 1969; Convention on Discrimination Against Women, 1981; Declaration on the Rights of the Child, 1959).

When it comes to human rights law and thus the types of rights that might be violated by businesses, there are a few key international legal documents that generally govern human rights: the International Covenant on Civil and Political Rights (ICCPR, 1966), the International Covenant on Economic, Social and Cultural Rights (ICESCR, 1966), and the Universal Declaration of Human Rights (UDHR, 1948). These are collectively known as the "International Bill of Rights." However, these documents apply to States and do not provide for direct liability of private individuals or corporations. The United Nations Office of the High Commissioner for Human Rights further explains that:

Human rights entail both rights and obligations. States assume obligations and duties under international law to respect, to protect and to fulfil human rights. The obligation to respect means that States must refrain from interfering with or curtailing the enjoyment of human rights. The obligation to protect requires States to protect individuals and groups against human rights abuses. The obligation to fulfil means that States must take positive action to facilitate the enjoyment of basic human rights. At the individual level, while we are entitled our human rights, we should also respect the human rights of others.

Thus, provisions in the International Bill of Rights are instrumental in demonstrating the human rights that States must ensure and protect, even if the violations are being committed by corporations, as well as what rights corporations should be mindful of. 


\section{GOOGLE IN CHINA: CENSORSHIP ISSUES IN THE INTERNET SERVICE INDUSTRY}

While Internet Service Providers are designed to provide information and related services to users, if they want to operate in certain countries they must often balance these activities with laws in those countries that require censorship or restricted information access, even when such censorship may be in violation of the countries' international obligations, as explained in detail below. Google's experience in China first began in 2000 when it developed a Chinese-language interface for its main website, Google.com (Schrage, 2006). However, over the next five years, Google's services in China were unavailable as much as ten percent of the time, and often slow and generally unreliable for users in mainland China (Schrage, 2006). Even the reachable services were almost always slower than Google's local Chinese competitors (Schrage, 2006). This was said to be largely because Chinese laws required extensive filtering even by smaller ISPs, which Google had to go through since it did not actually operate servers in China at the time (Schrage, 2006). The variation of filtering mechanisms maintained by each ISP led to a wide range of inconsistent outcomes that differed depending on time of day and location (Schrage, 2006). This diminished service was creating serious consequences for Google's market share. In fact, Google found that not operating with a local presence was "a major - perhaps the major - factor behind steadily declining market share" (Schrage, 2006).

For over a year, Google's management studied the positive and negative aspects of entering China (Schrage, 2006). Then on January 27, 2006 Google officially launched a search page based in China: Google.cn, opting to accept certain censorship requirements. According to local laws, Google would have to censor its search results, which it considered to be a "trade-off to 'make meaningful and positive contributions' to development in China" (Lee, 2010). For three years Google engaged in the Chinese market from Chinese soil without too much controversy or complications. However, in March 2009, China blocked all access to YouTube (BBC NEWS Business, 2010) and then in June, it began to mandate filtering software on all new PCs sold in China (Lee, 2010). Google's Gmail, Google.com site and other services became inaccessible in China the day before a Chinese official accused Google of spreading obscene material through its Internet services (Lee, 2010).

In January 2010, Google announced that it would no longer accept China's censorship demands and threatened to pull out of China altogether (Lee, 2010). China retaliated by calling this a Western stance and attacked Google for having close ties with the White House (BBC NEWS Business, 2010). By March 22, 2010, Google began automatically redirecting all customers from mainland China to its Hong Kong site, Google.hk, which was completely uncensored due to Hong Kong's independent legal system (BBC NEWS Business, 2010). China claimed that it would not renew Google's Internet Service Provider license under these circumstances. In June, China's preliminary list of license renewals did not include Google (Lee, 2010). Immediately following this, Google said that it would stop automatically rerouting Chinese customers to Hong Kong. Rather, users would have to actively choose to be redirected out of Google.cn and to Google's Hong Kong site (BBC NEWS Business, 2010). On July 9, 2010, China renewed Google's ISP license (Lee, 2010). Though the exact terms of the agreement are unknown, it was declared a victory for both sides because Google was able to continue operating from within China and Chinese users have the option of using Hong Kong's uncensored search engine.

However, now in 2014, as a result of Google's refusal to continue to censor its Internet content at the demand of the Chinese government, which would contrast with international human rights law standards, the Chinese government has recently been blocking Google's services in China again, particularly in the days leading up to the 25th anniversary of the Tiananmen Square incident (Roberts, 2014). In order to fully understand this situation and others like it, this article will discuss the ethical and legal implications of corporations taking steps to protect human rights. Overall, the aim of this article is to create a candid analysis of the accountability businesses should or should not have in human rights protection, based on both corporations' legal responsibilities to their shareholders and the rights of people to have basic human rights. 


\section{INTERNET SERVICE PROVIDERS AND HUMAN RIGHTS}

Without a doubt, Internet Service Providers play an instrumental role in advancing the freedoms of expression, speech and information, which are essential in advancing many human rights issues. Furthermore, the freedom of expression is considered to be vital to human rights, as the Inter-American Court of Human Rights explained:

Freedom of expression is a cornerstone upon which the very existence of a democratic society rests. It is indispensable for the formation of public opinion. It is also a conditio sine qua non for the development of political parties, trade union, scientific and cultural societies and, in general, those who wish to influence the public. It represents, in short, the means that enable the community, when exercising its opinions, to be sufficiently informed. Consequently, it can be said that a society that is not well informed is not a society that is truly free (IACHR Advisory Opinion, 1985).

Thus, when Google had to make the decision regarding whether to abide by China's censorship demands or forego operating in that country and sacrificing potentially large profits, it also had to face the question of whether or not it should be concerned with violations of freedom of speech and information at the expense of profits.

A country that violates the right to freedom of information may be in violation of its international law obligations. There are two main provisions in international law that are directly on point when content censorship is at issue: Articles 19 of both the ICCPR and the UDHR. Both apply to States in most situations. Article 19 of the ICCPR, which was signed by China in 1998 and is now considered customary international law and thus must be respected by all countries, states that:

1. Everyone shall have the right to hold opinions without interference.

2. Everyone shall have the right to freedom of expression; this right shall include freedom to seek, receive and impart information and ideas of all kinds, regardless of frontiers, either orally, in writing or in print, in the form of art, or through any other media of his choice.

3. The exercise of the rights provided for in paragraph 2 of this article carries with it special duties and responsibilities. It may therefore be subject to certain restrictions, but these shall only be such as are provided by law and are necessary:

a. For respect of the rights or reputations of others;

b. For the protection of national security or of public order (ordre public), or of public health or morals (ICCPR 1966).

Furthermore, Article 19 of the Universal Declaration of Human Rights (UDHR), which is a UN General Assembly resolution and not a treaty, but is also strong evidence of customary international law and thus binding all States under international law, asserts that "Everyone has the right to freedom of opinion and expression; this right includes the freedom to hold opinions without interference and to seek, receive and impart information and ideas through any media and regardless of frontiers" (UDHR 1948, emphasis added).

While exemplary, both of these documents apply only to States. Under international law to date, these obligations do not legally apply to corporations. Therefore, the question of whether a corporation could be liable for violating human rights if it complies with government censorship requirements remains unanswered. There have been, however, public concerns that Google may be or have been complicit in China's suppression of its citizens' human rights by agreeing to censorship demands. Such concerns are raised when a company "contributes to, or is seen as contributing to, adverse human rights impacts caused by other parties" 
(Guiding Principles, 2011). Before going further, it is important to understand what complicity means, to the extent that there is a limited understanding of what it takes for a corporation to be complicit in human rights violations. John Ruggie, the author of the UN Guiding Principles on Business and Human Rights, which will be described in detail below, explains that complicity has two different meanings, both non-legal and legal:

As a non-legal matter, business enterprises may be perceived as being 'complicit' in the acts of another party where, for example, they are seen to benefit from an abuse committed by that party. As a legal matter, most national jurisdictions prohibit complicity in the commission of a crime, and a number allow for criminal liability of business enterprises in such cases. Typically, civil actions can also be based on an enterprise's alleged contribution to a harm, although these may not be framed in human rights terms (Guiding Principles, 2011).

With regard to the non-legal interpretation, it is possible that Google could be seen as benefiting from maintaining business in China by agreeing to China's demands to censor some material. However, that would be the case for all foreign Internet Service Providers, including Microsoft and Yahoo!, as well as any other company that does business in China and pays taxes to the Chinese government and complies with national Chinese laws. Therefore, while an argument could be made that Google has been or is being complicit in this sense, it does not seem to be a particularly strong argument considering how broadly sweeping it would be, at least in the legal sense.

On the other side of the spectrum, even if one wanted to argue that a corporation, such as Google, does have human rights obligations, which in this case would involve the right to freedom of information or expression, then an ISP entirely refusing to operate within a country could itself, in fact, appear to be a violation of this obligation. For example, in a CASS Internet Survey which found that in China "'the political impact of the Internet is more significant than it is in other countries. The impact can be seen not only in the relationship between government and citizens but also among people who share similar political interests. Thus, we can predict that as Internet becomes more popular in China, the impact on politics will be stronger'" (Schrage, 2006). This ties in with the Inter-American Court of Human Rights' discussion on the importance of freedom of expression to human rights (IACHR Advisory Opinion, 1985, para. 70). As such, this was an important factor in Google's decision to enter China in the first place. As Elliot Schrage explained, by bringing its information and communication technology to China, including services such as "email, instant messaging, web logs, bulletin boards, podcasts, peer-to-peer applications, streaming audio and video, mobile telephones, SMS text messages, MMS photo-sharing," Google has provided opportunities for Chinese citizens "to read, discuss, publish and communicate about a wider range of topics, events, and issues than ever before" (Schrage, 2006). As Schrage further explained, if Google were to withdraw completely from China in protest to censorship demands, it would severely reduce "the opportunity for individuals to find relevant information. Consequently, individuals [would] have less information to make important decisions regarding economic transactions, and form independent opinions on political, social, or human rights issues" (Schrage, 2006). As such, when an ISP decides to acquiesce to some censorship demands in order to bolster the freedoms of information and expression in a country, it can perhaps be deemed not to be complicit in the country's censorship, but to be respecting the human rights of the people to receive and impart information.

This of course is also an argument that is a bit far-reaching. However, since the state of human rights and businesses is still very uncertain and emerging, far-reaching arguments seem to drive the debate. As this debate has raged on, one man has been able to create a set of principles that have reached some consensus: John Ruggie and his Guiding Principles on Business and Human Rights. Thus, it is relevant to drive the discussion forward and engage with Mr. Ruggie's Principles. 


\section{INTERNATIONAL STANDARDS ON BUSINESS AND HUMAN RIGHTS}

\section{JOHN RUGGIE AND THE GUIDING PRINCIPLES ON BUSINESS AND HUMAN RIGHTS}

The Guiding Principles provide practical and concrete recommendations to governments and companies on the policies and processes they may put in place to manage [human rights] risks (Ruggie, 2011, emphasis added).

This budding area of international law and human rights standards is embodied in the Reports by the United Nations Secretary-General's Special Representative for Business and Human Rights, John Ruggie. Most recently, Ruggie released the Guiding Principles for Business and Human Rights, which he explains, "seek to provide for the first time an authoritative global standard for preventing and addressing the risk of adverse human rights impacts linked to business activity" (Ruggie 2011). The UN Human Rights Council formally endorsed the text at its June 2011 session. The Principles build upon the United Nations' "Protect, Respect and Remedy" Framework, which is explained as follows:

The first is the State duty to protect against human rights abuses by third parties, including business enterprises, through appropriate policies, regulation, and adjudication.

The second is the corporate responsibility to respect human rights, which means that business enterprises should act with due diligence to avoid infringing on the rights of others and to address adverse impacts with which they are involved.

The third is the need for greater access by victims to effective remedy, both judicial and non-judicial (Guiding Principles, 2011).

However, as the name implies, these are not law, but rather principles meant to guide states and corporations with respect to human rights. Ruggie explains this is in his Commentary to Article 12's discussion on businesses respecting the human rights outlined in the 'International Bill of Human Rights:' "The responsibility of business enterprises to respect human rights is distinct from issues of legal liability and enforcement, which remain defined largely by national law provisions in relevant jurisdictions" (Guiding Principles, 2011, Commentary to 12). In other words, at this point businesses should feel the moral pull towards respecting human rights, but will not face international legal liability, and will only face domestic legal liability if they violate national laws. As such, looking at the following emphasised language in the first three "foundational principles" on the corporate responsibility to respect human rights furthers this point:

11. Business enterprises should respect human rights. This means that they should avoid infringing on the human rights of others and should address adverse human rights impacts with which they are involved.

12. The responsibility of business enterprises to respect human rights refers to internationally recognized human rights - understood, at a minimum, as those expressed in the International Bill of Human Rights. . .

13. The responsibility to respect human rights requires that business enterprises:

(a) Avoid causing or contributing to adverse human rights impacts through their own activities, and address such impacts when they occur;

(b) Seek to prevent or mitigate adverse human rights impacts that are directly linked to their operations, products or services by their business relationships, even if they have not contributed to those impacts (Guiding Principles 2011). 
The Commentary to Paragraph 13 further explains that "The responsibility to respect human rights is a global standard of expected conduct for all business enterprises wherever they operate. [...] And it exists over and above compliance with national laws and regulations protecting human rights." When a violation or "adverse human rights impact" does occur, this Commentary holds that "Addressing adverse human rights impacts requires taking adequate measures for their prevention, mitigation and, where appropriate, remediation" (Guiding Principles, 2011). Even as Paragraphs 12 and 13 describe the responsibility, and in fact Paragraph 13 uses the word require, it must be pointed out that this is only describing what respect must mean according to Ruggie. It is still only in the terms of Paragraph 11 which claim that corporations should respect human rights. Therefore, even though Ruggie was able to incorporate words like require into the Principles, it was only in defining respect, not in stating corporations' legal responsibilities.

As mentioned above, while the Human Rights Council has formally adopted these principles, they are a reference for how corporations should act, and not legally binding. As Ruggie explained, the Guidelines are an "authoritative global standard for preventing and addressing the risk of adverse human rights impacts linked to business activity" (Ruggie, 2011). Furthermore, the Principles "provide a blueprint for companies to know and show that they respect human rights, and reduce the risk of causing or contributing to human rights harm" (Ruggie, 2011). However, the Guiding Principles are essential in outlining the ways in which corporations should respect human rights, such as undertaking human rights due diligence analyses and remedying any violations.

\section{DUE DILIGENCE: A KEY TO RESPECTING HUMAN RIGHTS}

According to Ruggie, all corporations should undertake a due diligence analysis in order to ensure that they are respecting human rights, thereby being certain they are not infringing on rights and if they are, then taking steps to address any adverse impacts (Ruggie, 2011). The Guiding Principles explain that a corporation's human rights due diligence "should cover adverse human rights impacts that the business enterprise may cause or contribute to through its own activities, or which may be directly linked to its operations, products or services by its business relationships" (Guiding Principles, 2011). Ruggie's Commentary included in the Guiding Principles explains that "human rights due diligence should be initiated as early as possible in the development of a new activity or relationship," and then must be revisited as "human rights risks may change over time as the business enterprise's operations and operating context evolve" (Guiding Principles, 2011, Commentary to 17). To return to our previous example, Google's corporate culture and decision-making process undertakes due diligence in an exemplary way. This can be seen in its debates and extensive calculations made while deciding whether to enter China in the first place (Schrage, 2006). Google continually monitors its human rights impacts and tries not to be complicit in any violations, which is evidenced by its broad analysis of the situation in 2010 and its lengthy decision-making process with regards to whether to continue doing business in China (Schrage, 2006). This on-going analysis is part of the Guiding Principles' due diligence requirement which is key to a corporation's duty to respect human rights (Guiding Principles, 2011). Additionally, companies have domestic legal obligations, such as duties to shareholders, which they must contend with, regardless of how dedicated they are to promoting human rights.

\section{LIABILITY TO SHAREHOLDERS AND DUE DILIGENCE}

Corporations may have a drive to respect human rights, but in many domestic legal arenas their actions must not conflict with their duty to shareholders, which is primarily to bring a profit. In the past, Google has been able to balance its legal obligations to its shareholders with its ethical drive to respect human rights. This is evidenced first in its lengthy decision-making process to go into China originally, as well as its reevaluations of the situation in China. Furthermore, by making such calculations, a company has achieved a two-fold victory: it has hopefully ensured its desire to respect human rights while also having taken an extra step to insulate itself from national liability or from shareholder dissatisfaction. As John Ruggie explained, "[c]onducting appropriate human rights due diligence should help business enterprises address the risk of legal claims against them by showing that they took every reasonable step to avoid involvement 
with an alleged human rights abuse" (Ruggie, 2011). However, as a corporation, Google has a legal duty to its shareholders and that is not to play the role of a human rights activist. In reality, despite the interests of the media and other players to insist that ISPs should be good "corporate citizens," companies such as Google were not created to promote human rights. Rather Google's dual purpose is (1) to make profits by (2) furthering technological innovations (Lynch, 2010). Legally, as a publicly-traded company in the US, "Google can only apply its 'Don't Be Evil' motto to the extent that it doesn't conflict with the interests of Google's shareholders. A publicly-traded corporation's duty to shareholders is normally fulfilled by maximizing profits through increased share price" (Lynch, 2010).

There is possibility, of course, that if Google was found to be complicit or engaging in human rights violations by censoring its content in China, the so-called "court of public opinion" could weigh in. If the public believes a corporation is violating human rights or is complicit in such violations, the public may chose not to use the services or products of that company and shareholders may elect to sell shares. This is also known as the "Wall Street Rule" or "Wall Street Walk" (Wall Street Walk, 2009). While any company's Board of Directors should contemplate the impact its decisions will have on the public opinion and the opinions of its shareholders, these are business calculations, not legal ones.

While Ruggie's Guiding Principles provide a very good external reference for how businesses should respect human rights, they are still suggestive and not legally authoritative (OECD Guidelines). Certainly, international law may move in that direction, but it simply is not there yet. Therefore, companies such as Google need not worry about whether their actions could have international legal consequences at this point in time with respect to Ruggie's Framework and Principles. Yet there is no doubt that Ruggie's "work has provided a structure for the debate and action on business and human rights to be built on" (Davis, 2011) and has led to or assisted many industries in maintaining standards and organisations designed to promote human rights.

\section{INDUSTRY STANDARDS}

Another point to consider regarding businesses' human rights standards is the voluntary initiatives that corporations may undertake with respect to human rights. The most universal of these is the United Nations' Global Compact, which is a collaboration of businesses and industry leaders that strives to promote corporate social responsibility and the respect of human rights by businesses (UN Global Compact). The Global Compact encourages "companies to embrace, support and enact, within their sphere of influence, a set of core values in the areas of human rights, labour standards, the environment and anti-corruption" (UN Global Compact). Yet, participation in the Compact, while admirable, is entirely voluntary and there is no solid enforcement mechanism for participation.

There are also many industry-specific organisations, as well. Of particular relevance to our example, Google is part of the Global Network Initiative, which was organised by several Internet Service Providers, including Google, Microsoft, and Yahoo! Inc., as well as nongovernmental organisations, such as Human Rights Watch, Human Rights in China and the Center for Democracy and Technology, among many others. The Principles and Implementation Guidelines of GNI "establish a framework to provide direction and guidance to the Internet and Communications Technology industry" (Global Network Initiative). The GNI Principles, in conjunction with the Ruggie Guidelines, hold that "Internet and Communications Technology companies have the responsibility to respect and protect the freedom of expression and privacy rights of their users, as well as avoid complicity in violations" (Global Network Initiative). Such complicity in violations would likely be agreeing to a country's censorship demands. However, this is not a legally binding organisation and in fact maintains nothing more than aspirational values and a forum to share ideas. 
Furthermore, even in the wake of the controversy between Google and China, GNI still considered Google to be a very important member company that upholds the values of GNI. In its 2010 Annual Report, during the midst of Google's decision concerning whether to stay in China or leave, GNI cited Google as good an example of what member companies are doing to promote human rights. The Report explains that "Google's implementation of GNI's Principles relies on corporate infrastructure to ensure that human rights concerns are mainstreamed into Google's business operations. To this end, Google has established protocols for ensuring consideration of free expression and privacy rights" (GNI Inaugural Report, 2010). Furthermore, it explained that Google implements the GNI Principles "through support of and engagement with individuals, organizations and entities that further the cause of user freedom of expression and privacy." For example, Google was commended for providing support to NGOs, engaging with governments on Internet freedom policy developments, contributing to Internet freedom initiatives, sponsoring awards for Global Internet activities, and sponsoring Internet freedom conferences (GNI Inaugural Report, 2010). While admirable, these are prime examples of the voluntary nature of human rights in corporate culture, which are far from stemming from a sense of legal obligation.

\section{CONCLUSION: A BALANCING ACT}

In conclusion, the complexities of ISPs' effort to balance activities in censoring countries, such as China, and efforts to respect international human rights standards with regard to censorship demands and obligations to shareholders demonstrate how challenging the area of Business and Human Rights can be. In many ways, Google seems to have abided by Ruggie's Principles and stayed true to its purpose. Though it may have been cooperating to some extent with China, in recent years many of its services have been inexplicably inaccessible in China as it has refused to comply (Jacobs, Buckley, and Wingfield, 2014), but it has still managed to promote the freedoms of expression and information by providing invaluable avenues for the Chinese people to collect and disseminate information. While Google has suffered disruptions in China in recent months due to its refusal to fully censor its content, by working within China and not taking stands that markedly drop its shares in one of the fastest growing Internet and Communications Technology market in the world (Jacobs, Buckley and Wingfield, 2014), Google is being true to its legal obligations to its shareholders as well as to the international human rights norms. Furthermore, Google seems to have exercised due diligence with regard to its human rights impact in China, even though it is not legally obligated to do so. Internet Service Providers have an important role to play in allowing the people of China to reform their government from within. This alone, may be a strong indicator of respecting human rights.

While John Ruggie has made a commendable effort to create a uniform set of guidelines for businesses regarding what their human rights obligations are, if any, and has in fact succeeded at getting many businesses, industries, governments, and the United Nations on board with supporting these principles, they are still only principles and have no legally binding effect. There may be emerging international standards regarding businesses and human rights, but they are not legally solidified. Thus, whether the law will rise to meet the needs of a changing world and create a system in which corporations can be held legally responsible for human rights violations they commit, or are complicit to, remains to be seen. For the time being, we must hold on to such a hope while satisfying ourselves with encouraging businesses to respect human rights and balance their drive for profits and advancements with the lives of people across the globe. 


\section{REFERENCES}

BBC. (2010) 'Google Says China License Renewed by Government', BBC NEWS BUSINESS. Available at: http://www.bbc. co.uk/news/10566318.

Compulsory Membership in an Association Prescribed by Law for the Practice of Journalism (Arts 13 and 29 American Convention on Human Rights), Advisory Opinion OC-5/85, Series A, No. 5 (13 November 1985).

Davis, P. (2011) 'John Ruggie: A Common Focus for Human Rights', ETHICAL CORPORATION. Available at: http://www. ethicalcorp.com/content.asp?contentid=7253.

Global Network Initiative Organisation. (2010) 'Global Network Initiative Inaugural Report', [Online]. Available at: http:/ / www.globalnetworkinitiative.org/cms/uploads/1/GNI_annual_report_2010.pdf .

Global Network Initiative Participants. Available at: http:/ / www.globalnetworkinitiative.org/participants/index.php.

Global Network Initiative Organisation. (2010) 'Global Network Initiative Principles', Available at: http://www. globalnetworkinitiative.org/principles/index.php.

Guiding Principles on Business and Human Rights: Implementing the U.N. "Protect, Respect and Remedy" Framework, Report of the Special Representative of the Secretary-General on the issue of human rights and transnational corporations and other business enterprises, John Ruggie, Advanced Edited Version, "Introduction to the Guiding Principles," Human Rights Council, A/HRC/17/31 (March 21, 2011)

International Convention on the Elimination of All Forms of Racial Discrimination, 660 U.N.T.S. 195

International Covenant on Civil and Political Rights, GA res. 2200A (XXI), 21 UN GAOR Supp. (No. 16), UN Doc. A/6316 (1966); 999 UNTS 171; 6 ILM 368 (1967)

International Covenant on Economic, Social and Cultural Rights, GA res. 2200A (XXI), 21 UN GAOR Supp. (No. 16) at 49, UN Doc. A/6316 (1966); 993 UNTS 3; 6 ILM 368 (1967).

Jacobs, A., Buckley, C. and Wingfield, N. (2014) 'With Microsoft in Sights, China Starts to Squeeze U.S. Tech Companies', The New York Times [Online]. Available at: http://www.nytimes.com/2014/07/29/business/microsoft-offices-in-china-aretargets-of-authorities-visits.html?_r=0.

Ku, Julian G. (2011) "The Curious Case of Corporate Liability Under the Alien Tort Statute: A Flawed System of Judicial Lawmaking." 51 VA. J. INT'L L. 353 (2011)

Lee, M. (compiler), (2010) 'Timeline - China Approves Google Search Page', edited by Derek Caney. Available at: http:/ www.reuters.com/article/2010/07/09/google-china idUSN0926953020100709.

Lynch, E. M. (2010) 'Google er China: Is it Really About Censorship', CHINA LAW AND POLICY. Available at: http:/ / chinalawandpolicy.com/tag/googles-profits-in-china/.

"OECD Guidelines Feature in UN Special Representative's Survey of Business Practices." OECD DIRECTORATE FOR FINANCIAL AND ENTERPRISE AFFAIRS. Available at: http://www.oecd.org/document/11/0,3343, en_2649_34889_37519947_1_1_1_1,00.html.

Office of the High Commissioner for Human Rights, "Business and Human Rights," Available at: http://www.ohchr.org/EN/ Issues/Business/Pages/BusinessIndex.aspx.

Roberts, D. (2014) 'Google Blocked as China Beefs Up Security on Tiananmen's 25th Anniversary', Bloomberg Business Week. Available at: http://www.businessweek.com/articles/2014-06-03/google-blocked-as-china-beefs-up-security-ontiananmens-25th-anniversary

Ruggie, J. (2011) 'UN Guiding Principles for Business and Human Rights', The Harvard Law School Forum on Corporate Governance and Financial Regulation, [Online]. Available at: http://blogs.law.harvard.edu/corpgov/2011/04/09/un-guidingprinciples-for-business-human-rights/.

Schrage, E. (2006) "Testimony before the Subcommittee on Asia and the Pacific, and the Subcommittee on Africa, Global Human Rights, and International Operations, Committee on International Relations, U.S. House of Representatives," (15 February 2006)

Stanford Business. (2014) 'Doing the 'Wall Street Walk' as a Kind of Shareholder Activism', Stanford Business. Available at: http://www.gsb.stanford.edu/news/research/finance_admati-pfleiderer_shrholderactivism.shtml.

Universal Declaration of Human Rights, G.A. Res. 217A(III), U.N. GAOR, 3d Sess., U.N. Doc. A/810 (10 December 1948).

United Nations Global Compact. Available at: www.unglobablcompact.org.

United Nations Office of the High Commissioner for Human Rights. Available at: http://www.ohchr.org/EN/Issues/Pages/ WhatareHumanRights.aspx. 